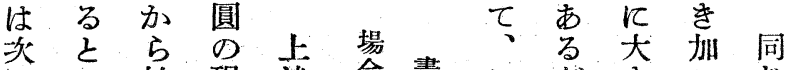

の 始現述 含畫で们き

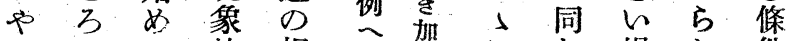

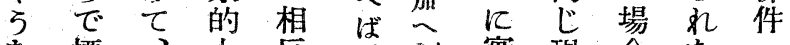

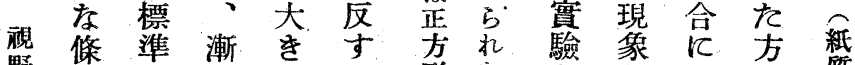

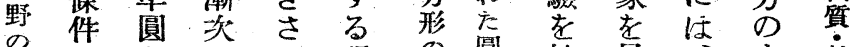

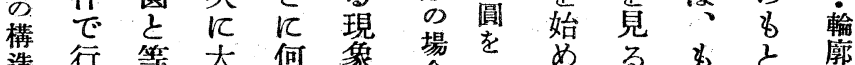

造行等 大

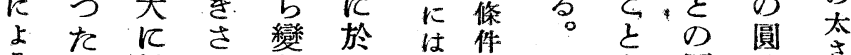

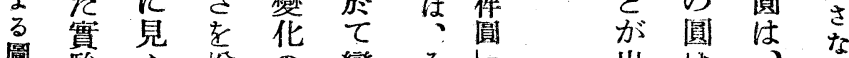

圖驗 $\therefore$ 懀 の 變そと

の 賽次 ᄂ

琴驗 第

的第第々边條修圆

大二却:之件件を

きのつき

變果縹 最合 條 型圆

篟资準初多件此條

に於圓は考圓跤件

万文標 $ぇ の$ 正圆

心明準方大方を

て膫反 圓れき形持

に少よる。吉な

香示さり譯の 標

池さく施を み

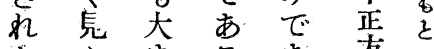

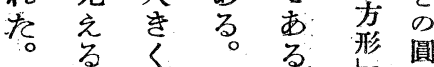

に見即方学を

到之充方呼梅

万扎條、準

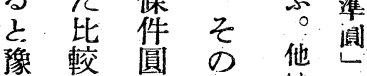

出洋他 ぞ

来逆他劣

小圓以

$\tau$ 崩 $\tau$

的胃

野

の

構

造

に

のく比 畫

d

や見較 力

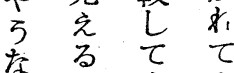

圖

な无形

現まきる つ

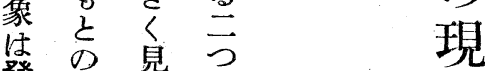

發圓之党の

生寊元等北农

的 $b$ 大 州的

如少 之

何さのの

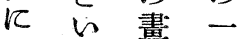

說同を方

明心加に

せ圓へ少

方

る 畫㞦大

期圓が大はを ばきるきき

さは比き礼呼导加同な

各心同

るん圓の 準学

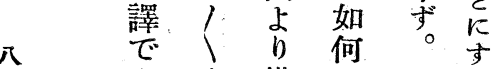

五あ小, 僅に市

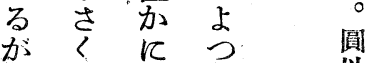

がく

こ 己 き は

乙、場 比

『圓心

之場 が 圓

國

ま

言合名

小稌 の

般 圓 加

的方占

設向 b る 朗

開注名

於逆韭賞

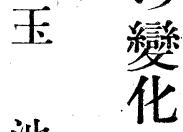

池

に

己あ 合輘型

の

苗

純 ひ

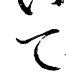


全梨

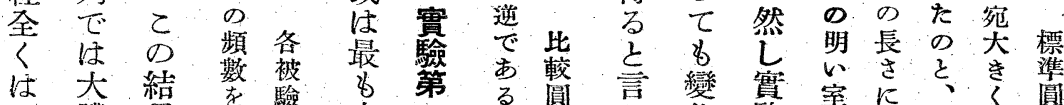

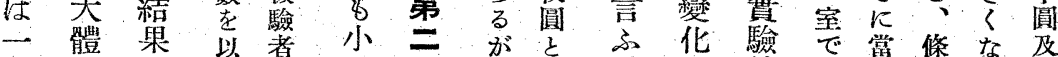

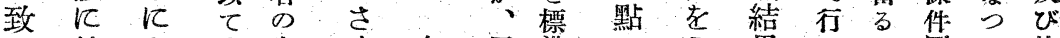

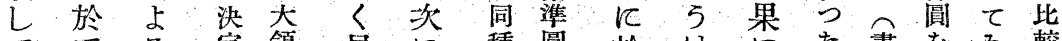

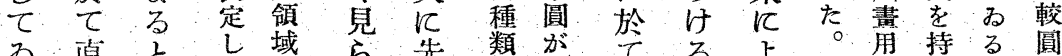

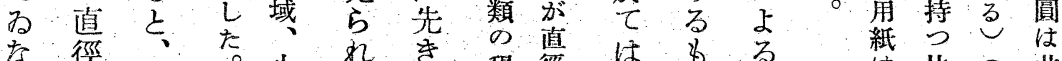

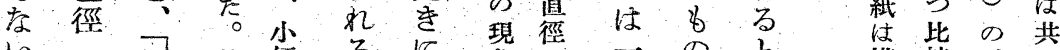

以

之 宽 領 條

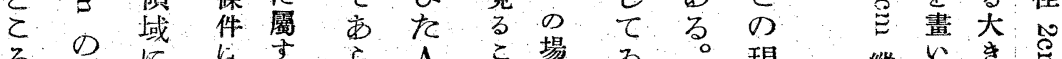

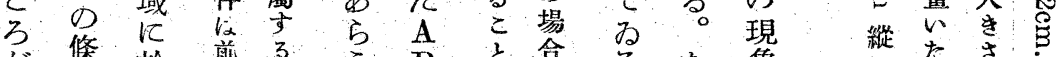

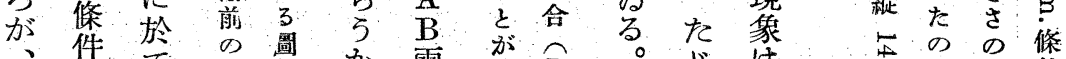

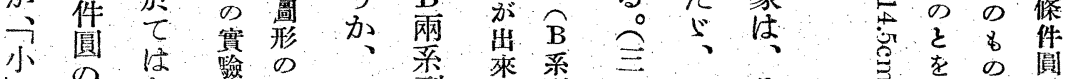

心

理

學

磁

笑

第

で相比 し 四

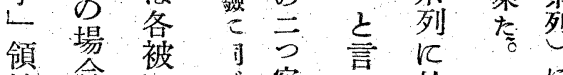

域合襝 宛方於

結 比者 ○ 全 問て

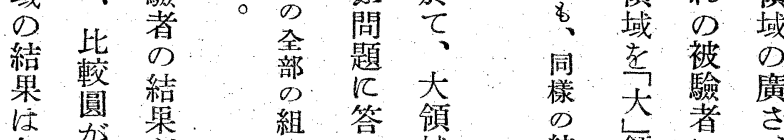

各最㤎等域 結 領者さ

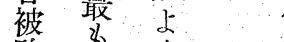

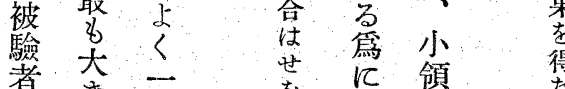

者 至致 作 次域

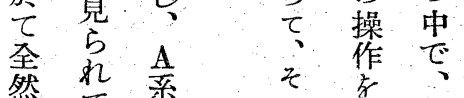

然怔菜

致 み で

老名は

缺: $\frown$ 道

ᄂ B 徑

被行

○

果域 8 位

あ し較て 輯

て 系 烈

了 $\sigma^{2}=$

場 合

第合件

驗

长 條

等 迅

るて、圆 は

ら被畫少

ち驗きな

昌者 加

圖は 圓

參 A D

㢣

せ

せ

め

๖

大

照亲場

列 合

場 B

合 系

或圓

或が

小

の

制

斷

犬

¿
領 や 於

條域 5 吕

件 交現 b

圓小玩 嗦の

領 が 個

烄域 あ人

圓

の

場

合

r

皆
と差

呼 點 落

己 ま し

r 三 X

寸 圖

の 形

領 提

域 示

現

象

大順

體序

決に
に眼た直

なのへ徑

つ高 A N

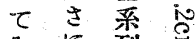

み $k$ 列

当並 。最

觀立圖 大

察立和。

距離蔥 方

は從白直

它つ徑

官兩畫苍

露方紙

䇥の の

時忠央々

間閏に食

は の畫間 六

心 距 当

離標范

觀畫隻 分

察用圆

は紙を。

通㮖畫官 

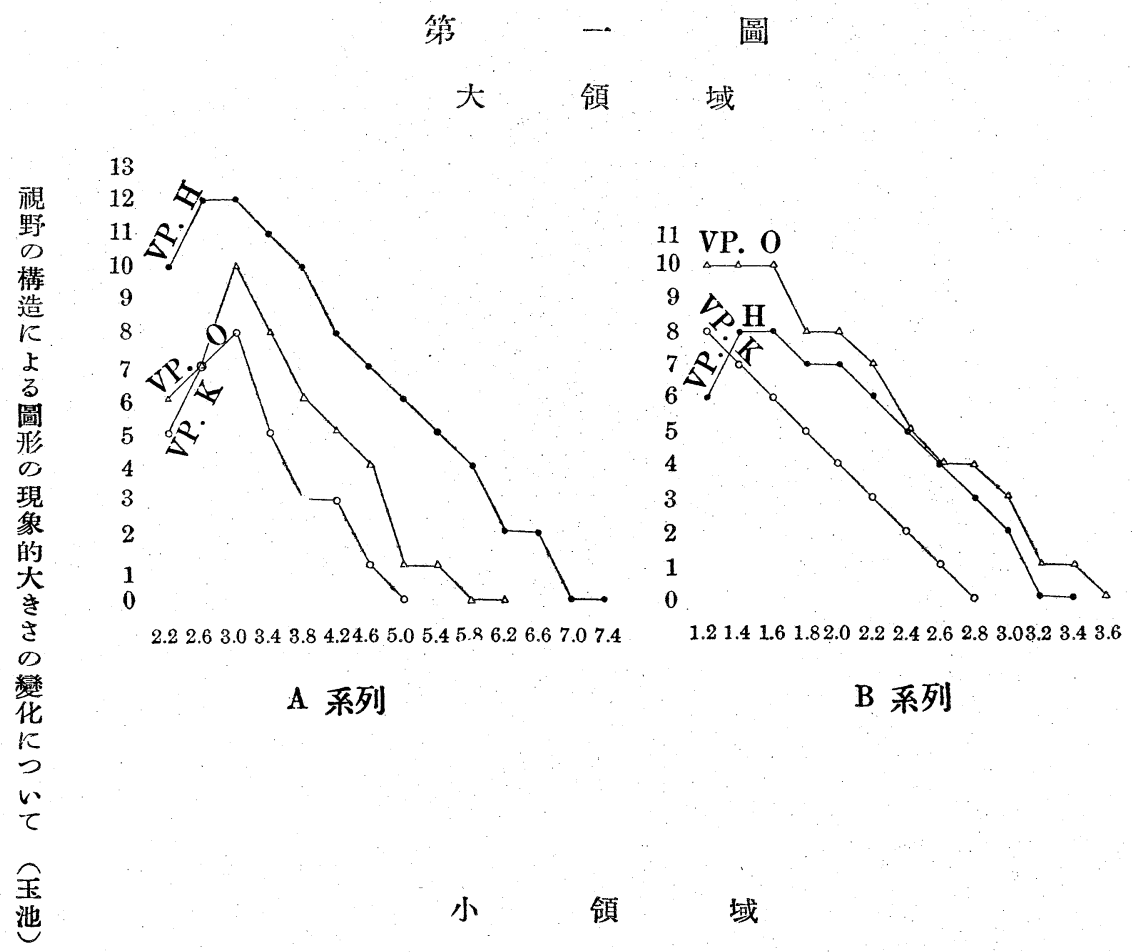

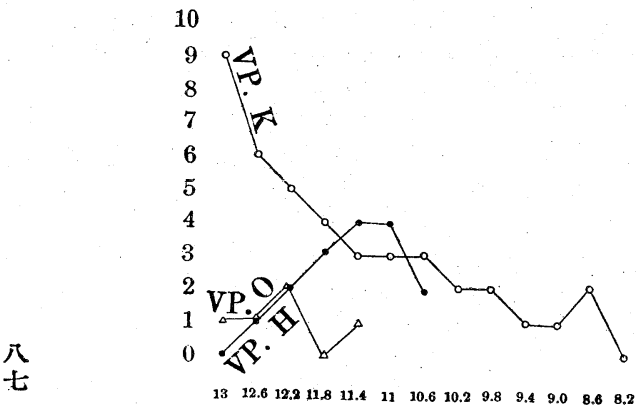

A 采列

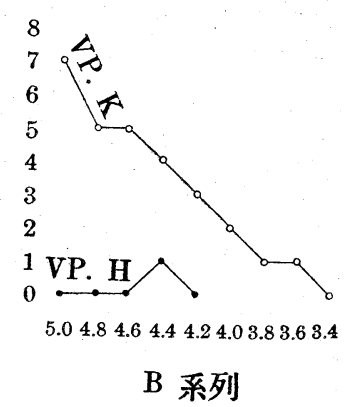

横軸八條件圆ノ直徑，縱軸八制断回數 


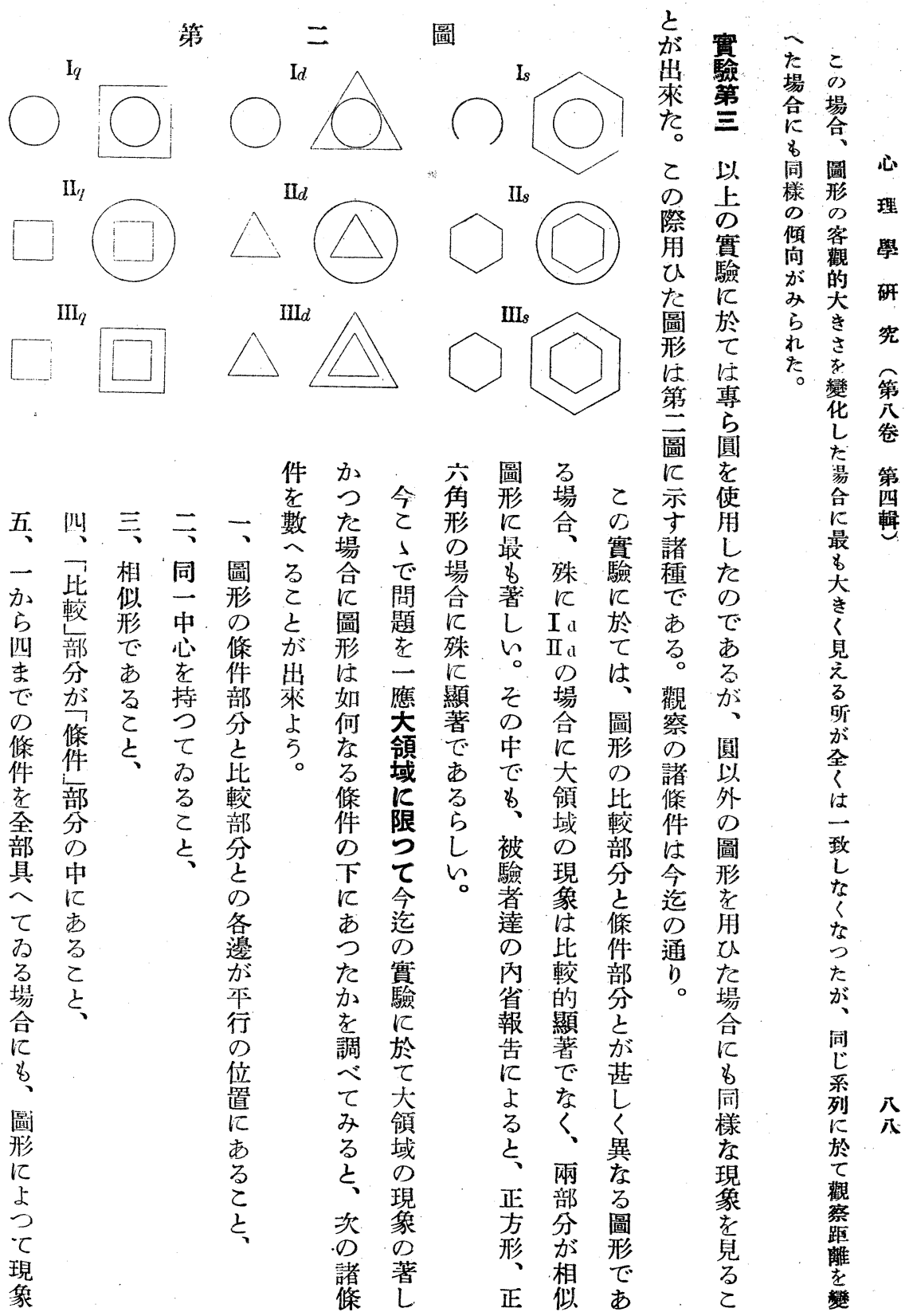




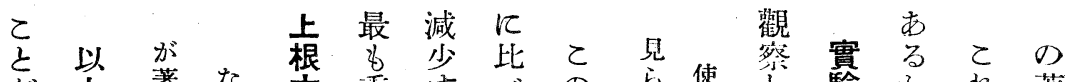
䧈占著

野ら 加公件作 $L$ 部於在形

の 峔 觀にでで條分で探は

陆た、察條あ、件市得用正

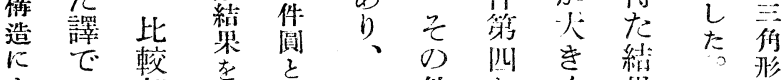

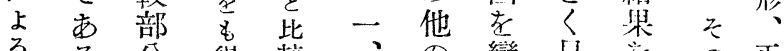

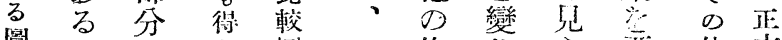

圖がが市圆二條化方要 他方

形、條、学

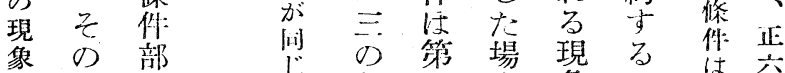

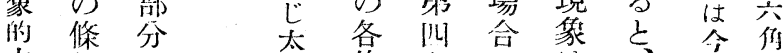

大件の さ條がには、远形

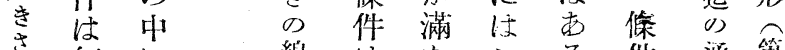

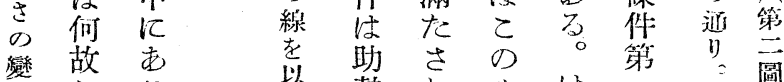

化とる

にの と

つ現

$r$ 秘

以

勢礼やけ一置

畫的 た 万狄、 III

学な上索第 III

れ 意门現

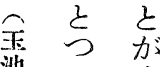

$\tau$ 味於像

照

るにて籍的

怨て大

場於現殆の

合て铺九條は

重 領

要 域

合重に炎件之

なの

要 好起紫衿

條 現

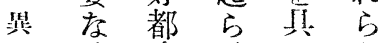

俳 像

之

た鋚合宗八力

な

$\tau \tau$

わ 最

万 4

重

で要

八あな

无背

5 件

办

乙 万

D 2

問

題京

太件索和た 二

さ 件從合宛

線るで采縞

を老て比化

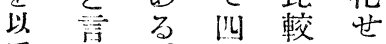

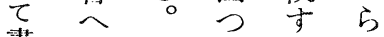

畫る郎の方狄

机。热條之た

條焂之件之埸

$\tau$

件中の合

第江著に

四於 L 女

は現は学

る
場
合
上
り
\&

現

象第程準

發, 四度阔!

炎

四或吕さ

は果に

乙 助 L 差

○) 梦

問的 現 が

題な乑放

孝意發る

解 味 生 加

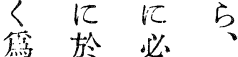

にて 慗圖

、必存形

-..要 條 の

店件何

川條でら

の件あ亦

各でるの

條あ性

件 る ど 質

老加学

- 加 4

つが、現

多閣义䇦

順題必に

次上要好

にな攵都

變つ市

化てる索

乙 桃之條

方号件

₹ \& な

の る

場根当

冬合本の

圖に的 が

現应 あ

に於恁意名

如测西

何於 あ

に て る

變必

化要

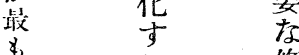

大多條

方华 
第三圖

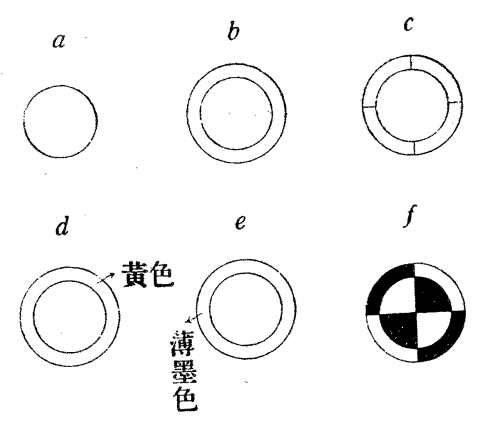

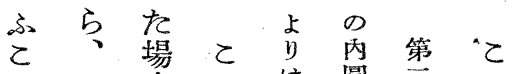

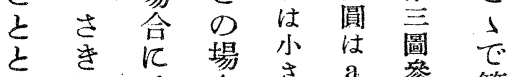

は違述注合学簡

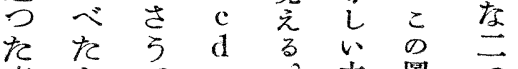

意あだ e た 圖

味るな在亲形

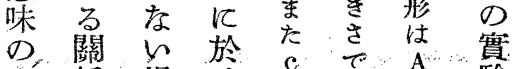

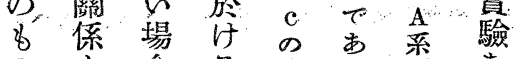

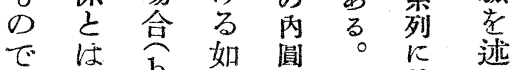

あこ b 如於 こ

る

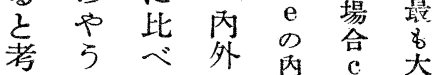

人にての㴘主き

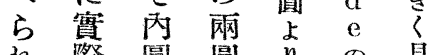

れ際圓圓 y

る作 がが㐫丙

圖小實 少圓 畐

的さ祭尖

結見圖学占占

ひ $ら$ 的見安大

つ礼衣大无

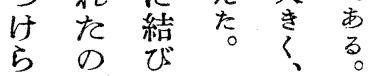

れで 0 b b

るあけ の c

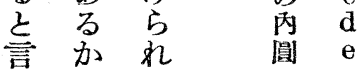

でに市趇係上的方解

万て 書於述條答

与把條き云件は

加握件し把

出 部て 握 の 根き

來分子粚助本儿心

なのるる勢的あ

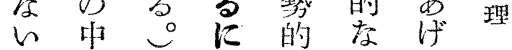

條に此好存條た學

件市較 都條件助

とる部合件汇斨 研

言上分店は好的

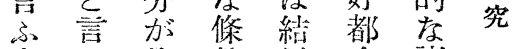

意亦像件 J出合諸

味乙件灾に存條第

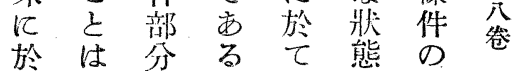

於は分劣 て 態意第

最方外圆提味置

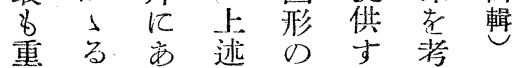

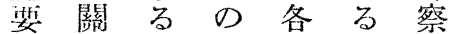

疗係場部 \&守

條に合の分のる

件於は場茂だ

をて、合をかと

な把兩にるらに

し 握、部 於 べでよ

乙分けくある

わ就方接る。て

る易乙圖近。そ

でい.

あ否言線、向

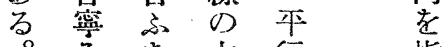

でさ るる

は 5 關に狀浆

で係つ態况

あなにいにる

關它方

係 は 把 觀で 握 察杂

ほ

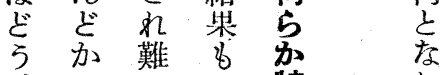

言子々と, 特犯

ふる频の 定代

と關 態と而 助

之係染之關勢 


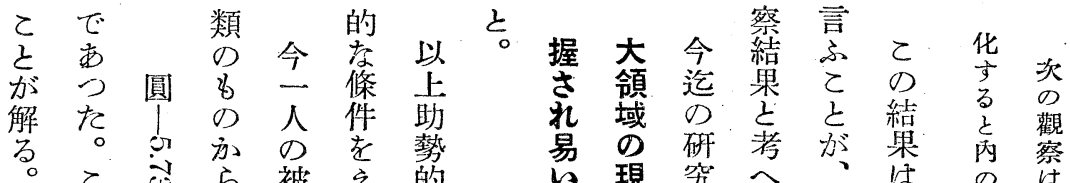

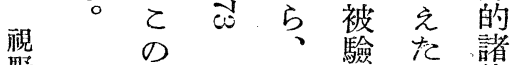

野結比者時條

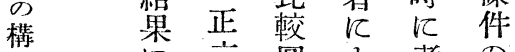

造六圆上考竞

占角等 て

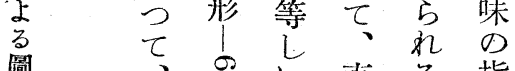

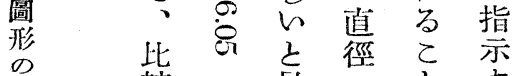

現較 見 $N$ 卞

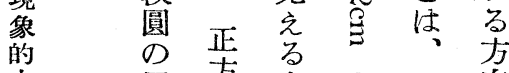

大周方名の乙向

園形の比の次

さ江山支較現從

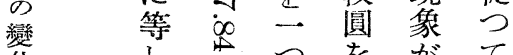

华しゅ老古て

尔 面 正 合 ち 積 本

て 面 焉拿計的

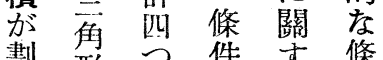

王劃形湂部 る 件

れ

て 出福考

わ L で察

るで圓は兄

か單、をて

ら單各正い上

比集條六亲述

較方件角ら口

圓 糎 圖 形 5 結

㤎形方論

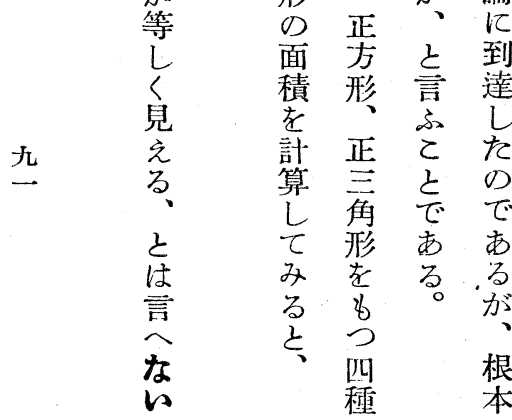

狀鐌究

態疟ら应の第

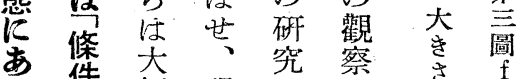

る 件 領現究祭さ

時部域爱於於戀吊

に分の の て

起 現助取 $d$ す

る 比稚勢 $b$ e る 外

較に的扱 の が 部

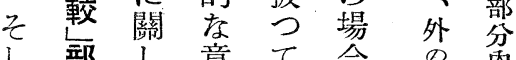

$L$ 部 $L$ 意 $\tau$ 合

$\tau$ 分て 味

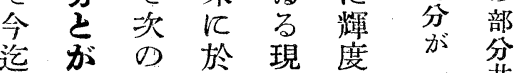

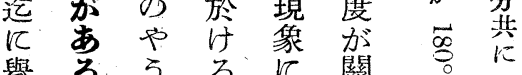

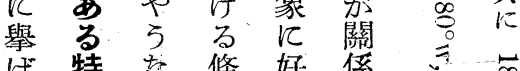

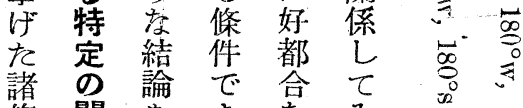

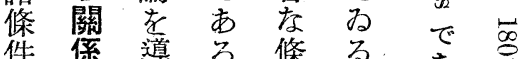

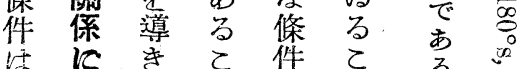

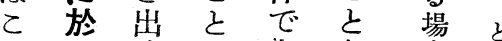

のて守があ南合方

や垈解方教郎方

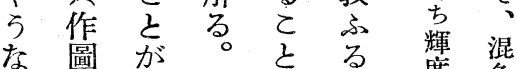

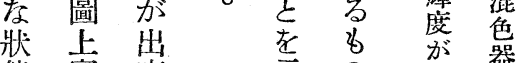

態蔓來示の 方器

海 る 尔で嵄圆

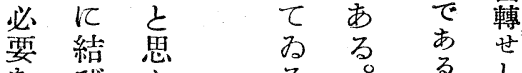

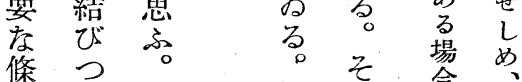

件け 郎第杂合外

でら ち市圖占苜部

る る b 時聂分

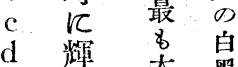

な゙ $\mathrm{d}$ 喓哭墨

な圖のく割

ᄂ 形羕觉合

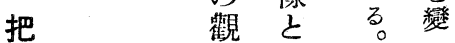




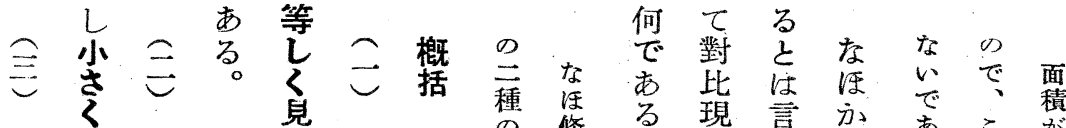

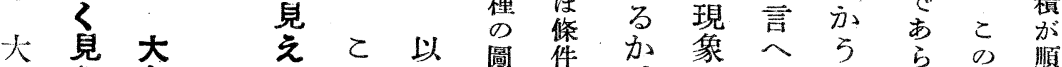

き交きの上形第、がな言方場奖

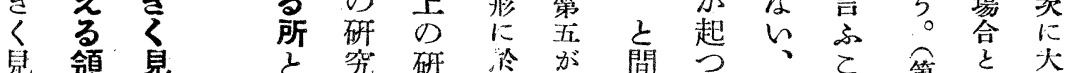

見領見究研佟肪問方、第等

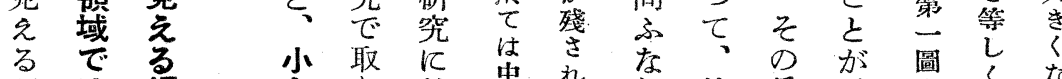

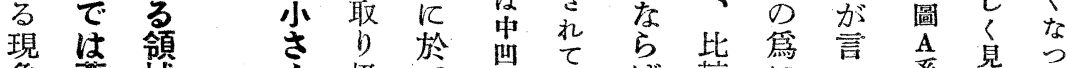

像著 域

住 $L$ K

紫不管

部競不個

分茂人

焂京差

件

部

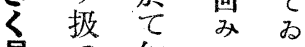

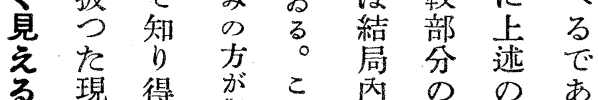

心

る 現得唯热队外の亦

理

所象た㢣 整

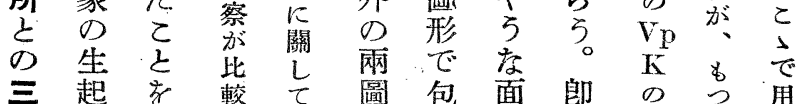

外聴や占

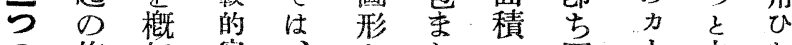

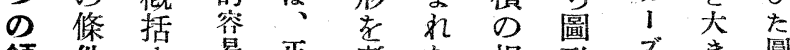
研

領件守易焉考た。相形

域たる染方察違面

參只思

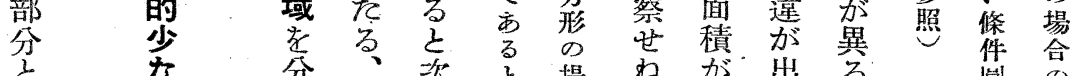

$\stackrel{\text { 年 }}{\text { な }}$

圖

け 條の 言合ば小乘場

形殊

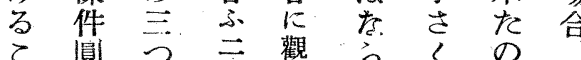

㤎质最

特年年

安

定

㐿交

於当所

热度

乙 圓 $\begin{aligned} & \text { 乙 } \\ & \text { 己 }\end{aligned}$

賽

は 領

が大な

湈さ争。

网. 此

或で之

的在再独

る。變

然 $r$

ᄂ

省 較

の大 方

阅

圖

合は

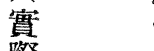

<. 域䘡

一 $\supset$ 圓

致

i

圆置

卡䆚

て

は 個

は当

結

人見

合

巳

な

¿

美爷

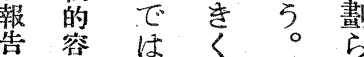

暴な見之礼

得で加えした

あ

る 5 の比芯

み三。部部さ

で领

ら分 の

5, 分

の、周 積

之園 滆

谽

乙 然面 じ

に對の味

反比廣を

ᄂ. 現 狹 持

便 r

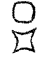

在從灭

क

了被

譯 驗

あ

名方

b $\tau$

必踥

ず 㴘

し が

最

常

こ

順見旮

序光

でる

あ.場

る 命

はは

限な 究 第 卷 第 四 輯 


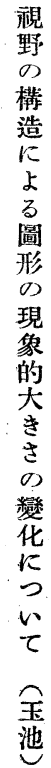

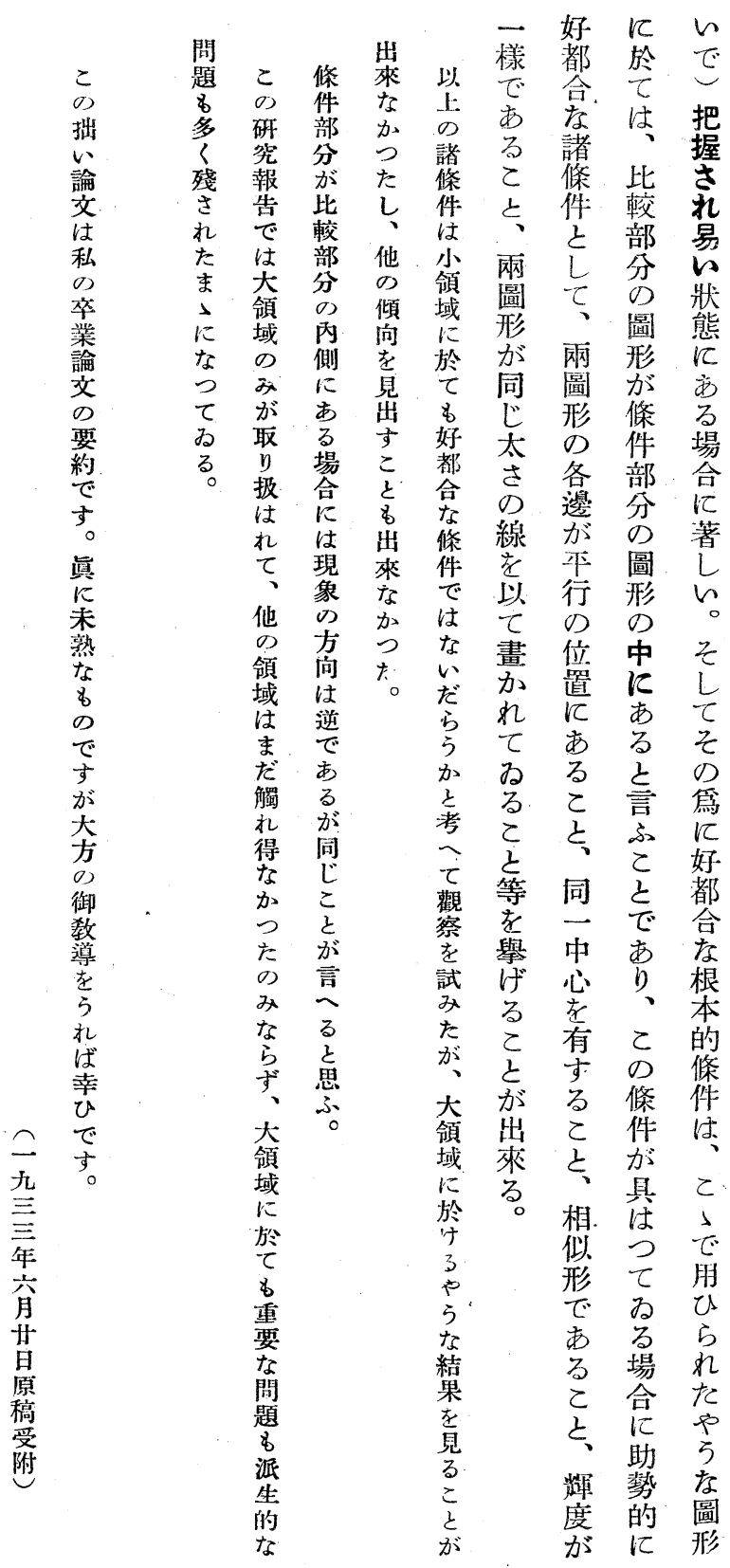




\title{
On the Change of the Phenomenal Size of Figure in Correspondence with the Structure of the Visual Field
}

by

\author{
Junrô Tamaike
}

Kŷ̂sĥ̂ Imperial University

A circle, accompanied by another concentric circle outside, appiars phenomenally larger than that of the same size with no concentric one. When the outer concentric circle ('conditioning circle') is enlarged gradually, we have such experience that the inner circle ("conditioned circle') diminishes in size, until it appears to be smaller than a circle of the same size without the concentric one. (Naturally, there is a region where both circles, the single and the 'conditioned' one seem equal.) Everyone experiences such a phenomenon, but everyone does not experience it equally. There are individual differences among observers. In enlarging the outside circle, or the 'conditioning circle' according to the writer, the range of region where the inside circle, or the 'conditioned circle', appears larger or smaller than the single circle varies among observers. They coincide in the maximum point in the region in judging the 'conditioned circle' larger, while they fail to agree in their judgement of the circle becoming smaller.

We can also experience the phenomenon using other kinds of figures (triangle, square, hexagon etc.).

The phenomenon which occurs in the region of the judgement 'larger' is remarkable, when the following conditions are fulfilled:

The 'conditioned figure' lies inside the 'conditioning figure' (This is the most important conditions.).

The above-mentioned figures are concentric, of similar figures in similar positions and are drawn on a plane of the homogeneous brightness.

They are thus perceived at once in close connection each other, but they are not figurally connected. 